\title{
PHILOSOPHY AND MYTH. THE AXJOLOGY OF LESZEK KOLAKOWSKI
}

\author{
Aldona MUSIAE-KIDAWA \\ Politechnika Śląska, Wydział Organizacji i Zarządzania; aldona.musial-kidawa@polsl.pl, \\ ORCID: 0000-0001-9525-6348
}

\begin{abstract}
Purpose: The publication presents the issue of philosophy understood as the creation of an ethical sense of humanity of a human being.

Methodology: The main method is the analysis of the subject literature.

Findings: The publication discusses issues related to the status of man as a being above biological, having the ability to identify categories of good and evil.

Social implications: Considerations concerning the moral dimension of human existence may determine the future of European civilization.

Originality/value: The publication indicates that exceeding utilitarian criteria builds the awareness that man is a moral entity, which is an end in itself, never a means.
\end{abstract}

Keywords: man, morality, awareness, freedom, subjectivity, myth

Category of the paper: Conceptual paper, General review.

In his work, Leszek Kołakowski focuses primarily on philosophical concepts of human existence. The philosopher is interested in man as an individual being and subject who feels the alienation of the world and the alienation towards the world. The tragedy of human existence is a state of suspension between two biological orders and intellectual and rational ones. This antagonism of nature and culture manifests itself in attempts to overcome an enlightened structure, to alienate man, and at the same time to become a temptation that constitutes the concept of the uniqueness of every human being. This concept contains an affirmative conviction that moral principles, which cannot be empirically proven, are a condition for human development and survival in the world. Kołakowski notes that "man" is not an entity defined by the features of a zoological species, but "man" is an abstract category conditioned by a moral imperative.

Philosophy, its status from an epistemological perspective, is defined by a transcendental search for real life, by knowing existence from the perspective of the necessary raisons d'être, by contrasting it with the coincidental, sanctioning practical consequences of the dichotomies of "truth" and "falsehood", the quality of the realities that are the expression of the human communication process, a process that is outside the reference of relationships that reveal the 
relationship of the human mind (judgement) to the reality "in itself". This perspective is the centre of interest of Leszek Kołakowski, who notes that philosophy is an expression of the human being's humanity, because "love is not only a drive for procreation, and the idea of home has in itself something that does not fit into the very concept of a shelter, which implies a cognitive situation of a human being that is realized at the level of consciousness of insight into a reality beyond empirical borders and beyond the limits of relativism" (Kołakowski, 1990). Kołakowski points out that philosophy strengthens its position by "accepting the result of criticism applied to the epistemological question" (Kołakowski, 1994), so that it situates philosophy outside of mythogenic activity and excludes its belonging to the technological trunk of civilization. Philosophy, its task, focuses on cultivating the spirit of truth, especially since "the animal order and the mythical order are turned against each other in an unfavourable suspicion - at least in a culture whose mobility does not allow it to be balanced by itself" (Kołakowski, 1994). Kołakowski notes that the synthesis of these orders is a danger for human survival. This situation constitutes the status and role of philosophy in a culture developing on the basis of two antagonistic ways of organizing the world explicitly revealing the expansion towards the pursuit of control over human life. Philosophy realizes the possibility of mediating in the dispute between technological and mythical consciousness, on the one hand, by excluding full synthesis, and through taking into account coexistence from the perspective of a permanent conflict - on the other. The mediation role of philosophy is defined by the consciousness of articulating meaning in the fundamental questions for the ethical survival of mankind: "how to distinguish good from evil, truth from false, real from unreal" (Kołakowski, 1999). This perspective allows us to determine the philosophy of autonomous status in relation to the mythological area, and hence to identify the reality of the world of man rejecting myth and the consequences of total negation of myth. Philosophy identifies myth and interprets it by indicating its sense-forming value for determining the quality of human existence and by sensitizing it to its degenerative function as a tool of domination and despotism, because it is "dangerous to believe that the values found and dissatisfied at any moment are ready and finished, that they can relieve us from the situational and situational interpretation of responsibility for them" (Kołakowski, 1994).

In his article Truth as a Myth, Kolakowski interprets the metaphysical meaning of truth as a quality that remains beyond the reference to cognitive situation and, at the same time, excludes the need for justification by indicating values that are the subject of empirical (technological) perception. Truth in the metaphysical sense covers issues developing on three levels of identification of the world (excluding the influence of legitimate scientific cognition): Kolakowski points out the problem of absolute genesis as the absolute beginning of the world and man, the problem of truth as the identification of permanent qualities of "everything", i.e. whether there is a "being" in opposition to "non-existence" and the problem of truth from the perspective of the quality of "necessity" of events, so as to identify the necessity beyond empirical conditions pointing to the reference to the inalienable "nature of existence" 
(Kołakowski, 2001). Kolakowski notes that metaphysical questions, being an opposition to the biological condition of man, reveal the area of existential anxiety constitutive for the world of culture in the mythogenic dimension, because "they aim at revealing the relativity of the world of experiences and try to reveal the unconditional reality, because of which the conditional reality becomes meaningful" (Kołakowski, 1994). The essence of human humanity is a consequence of the presence of metaphysical convictions organizing the dimension of human existence in order to realize the need for truth by referring it, together with the existing reality and one's own existence, to "nonempirical unconditional reality". Kolakowski sees, however, that the metaphysical area of human perception, indicating the supra-empirical reality of existence, indicates only the presence of intention, and not the real reality to which this intention is to be related. The intentional presence of mythical phenomena characteristic of our culture is an exemplification of the need immanent belonging to human nature. Kołakowski underlines the notion that revealing mythical reality points to the need to identify the sense of existence discovered in man, which is realized through final questions concerning the structure of human existence. Therefore, metaphysical questions are the construction of the mythical organization of the world that makes it impossible to convert them into scientific questions, because "the ability to command is the power of the analytical mind" (Kołakowski, 1994).

Kolakowski states that the identification (consciousness) of the non-empirical perception of the world reveals the presence of culture within which the discovery of an absolutely initial situation takes place, which refers the sense of everyday life to a non-relative reality. From this perspective, Kolakowski emphasises that myth is a desire for truth realizing the need to relate the empirical world to unconditional existence, moreover, that myth is a perception of "any possible experience" of the world relativizing this experience to the quality of transcendent "deliberately binding phenomena" (Kołakowski, 1994). Kolakowski points out that the absolute genesis revealing the problem of the deliberate order of the world, constructs the need for an "understanding grasp of empirical realities" in order to assign the notion of meaning to the experienced reality of the everyday world - the reality concentrated around the technological exploration of the world. The presence of myth indicates that in an intentional way there is a need to strengthen the teleological order that is beyond the empirical, which makes real the idea of humanity realized in human dignity.

The affirmation of the deliberate order of the world makes it possible to identify myth as an understanding interpretation of the reality present experimentally (Kołakowski, 1966). Kolakowski, noting the permanent quality of everything as an expression of myth-creating need, identifies the problem from the perspective of belief in the permanence of human values independent of the empirical identity of reality. The philosopher recognizes that the affirmation of personal values, constituting the consolidation of the desire for truth as a self-aimed value, determines the permanence of the quality of the effects of human actions and deeds (although they tend towards final absence) especially in the perspective of satisfying the hope of personal survival (although without imaginable justifications): "Such affirmation has the same kind of 
cultural legitimacy as other myth-creating acts, provided that they are the work of a real need" (Kołakowski, 1994).

Kołakowski points out that the need for myth identifies the problem of truth related to the desire to identify the world as a continuous world, going beyond the empirical structure of reality revealing its discontinuity at critical points. Herein, the volatility of the quality of the organic world prevents the constitution of rights and the regularity of events in order to determine their necessary, not merely phenomenal, character. Kolakowski holds that the need for continuity of transformations refers consciousness to the mythical structure realizing the order of the world in a timeless construction revealing the affirmation of humanity as a value overcoming the perspective of the regularity of human empirical existence: "is to avoid consenting to a random world, exhausting itself each time in its own perishable situation, which is what it is now and does not refer to anything" (Kołakowski, 1994). Kolakowski understands that the need to see the world as continuous, sanctioning a permanent intuition of the overempirical dimension of human existence, shows the essential, ontological basis of reality going beyond the perception of the phenomenal structure of the world.

Beyond the aforementioned, Kolakowski states that myth determines the existential dimension of human existence, because "myth means that we are not dealing with the assignment of the court to the situation it describes, but with the assignment of the need to the area that satisfies it" (Kołakowski, 1994). This indicates a permanent presence in the culture of mythical consciousness designing a transcendent desire for truth (the perspective of metaphysical final questions) realizing affirmation of values (beyond the phenomenal purpose of existence and the continuity and permanence of the world) and realizing and satisfying the need for a sensible experience of the world. Hence, the need to identify the world of experience is made through an understanding interpretation referring the conditional being to the unconditional reality. He points out that the presence of the myth "cannot be persuaded" because the myth, by exceeding the justification of scientific perception in its construction, remains outside the conditions of technological credibility. Kolakowski believes that philosophy alone participates in the cognition of the intentionally present reality by way of revealing the area of mythical consciousness, concentrating on the "restitution of myth in its primordial dignity" (Kołakowski, 1994). By raising the importance of philosophy for the presence of myth, Kolakowski underlines the importance of self-knowledge of the human condition, which is revealed through final questions conditioning the insight into mythical reality and through revealing the perspective of one-dimensional empirical reality. Philosophy, its task, is also to identify the absurdity of the relative world, which is exhausting in its selfsufficiency. The reality of the empirical world remains beyond the definition of its hidden meaning, so the absurdity of the world is an immanent feature only if it is recognized with "self-sufficient" reality. Furthermore, the clash between man and the world reveals the absurdity of existence from the perspective of human being and things being opposed to each other (Kołakowski, 1999). Philosophy, as it notes, opens the very possibility of interpreting the 
world of experience as a conditioned world (Kołakowski, 1994) and reduces the legitimacy of scientistic philosophy to the exclusive identification of the world, making present the area of existential anxiety, the area related intentionally to mythical reality. Kolakowski, noting that the experience of freedom is an exemplification of the act of transcendence of the existence of the cognitive subject, emphasizes the responsibility that is constitutive for the quality of freedom and determines the value of the existence of Good. Beyond this, it identifies the nonempirical status of human existence that legitimizes the awareness of dignity (Kołakowski, 1999), so that the affirmation of humanity is carried out at the level of moral imperatives that remain beyond the possibility of empirical proving and without the need to refer to empirical conditions. He sees that the identification of humanity in moral terms is beyond the reference to empiricism - the assumption of the freedom of man doing good and choosing evil is legitimate. Kolakowski is definitely looking for a permanent basis for strengthening the ethical consciousness that is the foundation of human reality, the consciousness that reveals the sense - good - of human activity, because "from what people do it is not allowed to derive what they should do" (Kołakowski, 1984).

The epistemological status of normative judgements is credible beyond the identification of moral attitude with the notion of usefulness. From the perspective of morally usefulness, any activity concentrating on the implementation of egoistic decisions or reducing phenomena only to the empirical analysis of verifiability established arbitrarily remains morally justified. Kolakowski stresses that the identification of good in opposition to existing evil is an expression of awareness of the distinction between this dichotomy beyond empirical conditions: the identification of good and evil remains outside the category of benefit and damage. Kolakowski reminds the reader of the Kantian perspective of humanity. He notes that this perspective reveals the opposition between the rule of duty, i.e. the mandatory norms, and the practice of social life which sanctions the reference to the moral presence of man to anthropology and psychology. Kolakowski emphasizes that the difference between duty and utilitarian social order is revealed by the qualitative verification of the question of what is morally right, the question of the human reality in the transcendental perspective of practical reason.

Beyond the aspect of duty, the question is why people believe that something is right or wrong. Kolakowski states that the fundamental issue for the consolidation of the idea of humanity is the determination of the legitimacy of the identification of good and evil, especially since the universal affirmation of ethical principles is not a credible premise conditioning the legitimacy of their validity and the need to respect them. Kolakowski also remind us of the consequences of the ethical nihilism threatening the attitude of human responsibility and, as a result, calling into question human freedom. Kolakowski indicating the transcendental conditions of practical cognition, recognizes that all forms and categories through which we identify and co-create phenomena of reality are not the expression of psychological properties understood as a set of random characteristics of man as a creature of nature, but are "necessary 
conditions for any possible experience" (Kołakowski, 1984), thus determining the position of all rational beings, because they concern reason, not zoological species.

The philosopher similarly identifies the function of practical reason as the authority ordering the will to obey the universal moral law (categorical imperative). These are the moral principles which establish the necessary conditions for the functioning of every norm that determine man to act on the basis of the autonomy of the will. Herein, the subjectivity of every rational being determines the possibility of moral action, that is, the ability to guide himself according to established rules. Kolakowski decisively points out that a similar perspective on the consolidation of morality constitutes the concept of mankind and humanity (Kołakowski, 2000), because "mankind is not a natural object, given in nature, and humanity is not a zoological concept, but a moral one". The philosopher notes that humanity as an unconditional area of duty is defined by the awareness of the necessity of cognitive "epistemologically expressed as a collection of a priori synthetic judgments, as well as identified in the sphere of unconditionally binding moral imperatives, which empirically establish unlike" (Kołakowski, 1984).

The justification of morality is therefore made outside empirical categories. Hence, morality absolutely conditioned by a priori categories remains outside the reference of material determining factors. In consequence, the principle of practical reason creating a sense of moral activity of man supports the conviction that the rules of conduct must not be derived from the observation of human activities: "the Kantian commandment that the rules of duty cannot be derived from what we actually do and that it is extremely important that, even when we are aware of these rules when we ourselves frequently violate them, they remain a condition for any society that does not want to disintegrate" (Kołakowski, 2000). Kolakowski allows us to see that the condition of contemporary civilization depends on the awareness of identifying good and evil, values whose legitimacy is determined not by the category of benefits and harm, empirically accepted, but by independence from time and place, indicating their universality and objectivity, because: "to say that moral rules coincide with utilitarian criteria is to say that there are no moral rules" (Kołakowski, 1984).

Kolakowski notes that the affirmation of an unconditionally binding system of moral values (a nonempirical interpretation of good) by setting the impassable limits of human activity determines the fate of man. Kolakowski also identifies the problem from the perspective of the fundamental law of nature to which man is subject, the law shaping man as a person participating in the reality of experience and going beyond it towards the constitution of ruthlessly binding norms in the autonomous sphere of practical reason (Kant, 2001). In accordance with the Kantan justification for humanity, he points out that the boundary between compliance with ethical norms is determined by the existence of a clear difference between natural urges and duties, between what we do and what we should do, since failure to identify this difference threatens the moral presence of man in the world, thus sanctioning the recognition of many forms of slavery revealed by situations of individual and state coercion. 
Kolakowski underlines the importance of the notion that the structure of human existence, while remaining outside the realisation of real harmony, is constituted by mechanisms of self-repair and self-defence, because without the transcendental certainty that the criteria of good and evil can be established, civilization will not survive at all (Kołakowski, 1984).

The transcendental justification of ethical norms, according to Kolakowski, weakens the empirical validity of good and bad criteria, especially since the reality of experience may exist beyond the identification of such concepts, empirically considered only from the perspective of psychological or social facts. By strengthening the value of human freedom through the postulate of practical reason, Kolakowski draws attention to the concept of abstract man as a requirement of human condition in the world, and consequently as a source of certainty for humanity, certainty justified beyond empirical empiricism. Faced with the issue of the transcendental horizon of human existence, Kolakowski points out that the perspective of the abstract man's reality remains the obligation of moral participation in the act of perception of another man (Kant, 2001). Moreover, this obligation constitutes the basis for the discovery of ethical norms in an unconditional form, because participation in humanity understood as a Kantan field of rational necessity, determines the responsibility and rights of people as moral subjects, so that this responsibility and these rights revolves around each other: "the image of a world stripped of all qualities subject to evaluation may be philosophically interesting, but it cannot claim to allow everyday life to be understood, let alone governed by practical attitudes" (Kołakowski, 1965).

The concept of abstract man, hence, is the basis for justifying the dignity of every freely acting creature, since it participates in the law of Nature which determines the inalienable equality of men and women. Kolakowski emphasizing the consequences of the convergence of the Kantian theory with the theory of natural law indicates that humanity is a moral category, so that every person as a person is obliged to affirm his own humanity always as an end, never as a means: "all norms, insofar as they have a moral content, refer to every individual without exception and there are also claims which every individual without exception can make, because every individual should be treated as an end in itself and not as a means" (Kołakowski, 1984).

The concept of abstract man, which indicates human nature as the proper basis for determining responsibility and human rights, consolidates the hierarchy of ethical values which determine the meaning of moral activity of man in the world, of every man. This concept, which strengthens the postulate of moral perfection of man, the postulate subordinated to the principle of practical reason that it is forbidden to derive rules of conduct from the observation of facts, i.e. utilitarian criteria, opposes the consequences of the concept of concrete man. Kolakowski points out that defending the Kantian heritage against the jargon of a specific human being is a condition of the value of human freedom, because it is a prerequisite for the value of human freedom: "every reasonable being who is willing to do so must also necessarily be given the idea of freedom, in the name of which he merely acts" (Kant, 2001). The concept 
of a concrete man legitimizes from the perspective of a conservative or revolutionary, the claim to an arbitrary hierarchy of values, in line with the economic situation of the historical moment, which sanctions the resignation from rules that are absolutely binding for the immediate benefit. However, the fundamental difference between projects organizing moral reality is based on the interpretation of objective laws (criteria of duty) that are the relation of people to each other as goals and means to the goal, because breaking and violating rules whose binding force is recognized is qualitatively different from their invalidation.

This difference is also the difference between good and evil, and thus the fate of man: "morality is an only condition upon which it depends that a reasonable being can be an object itself, because only through this it can be a lawmaking member in a society of aims. Thus, only morality and humanity, in so far as it is capable of morality, are what has dignity" (Kant, 2001).

\section{References}

1. Hoffe, O. (1994). Immanuel Kant. Warszawa: PWN.

2. Kamiński, S. (1989). Naukowa, filozoficzna $i$ teologiczna wizja człowieka. In: Jak filozofować. Lublin: KUL.

3. Kant, I. (2001). Uzasadnienie metafizyki moralności. Kęty: Wydawnictwo Antyk.

4. Kołakowski, L. (1966). Prawda i prawdomówność jako wartości kultury. Studia Filozoficzne, 2, 35-51.

5. Kołakowski, L. (1984). Czy diabet może być zbawiony i 27 innych kazań. London: Aneks.

6. Kołakowski, L. (1994). Obecność mitu. Wrocław: Wydawnictwo dolnośląskie.

7. Kołakowski, L. (1997). Bergson. Warszawa: PWN.

8. Kołakowski, L. (1999). Moje stuszne poglądy na wszystko. Kraków: ZNAK.

9. Kołakowski, L. (2000). Kultura i fetysze. Warszawa: PWN.

10. Kołakowski, L., Pomian K. (1965). Filozofia egzystencjalna. Warszawa: PWN.

11. Russell, B. (1997). Konflikt między technika a natura ludzka. In: Władza i jednostka. Warszawa: Książka i Wiedza.

12. Tischner, J. (2002). Spór o istnienie człowieka. Kraków: ZNAK.

13. Tischner, J. (2006). Filozofia dramatu. Kraków: ZNAK. 